\title{
Federalism as a Moderating Force? State-level Responses to India's New Citizenship Law
}

Loraine Kennedy

\section{CpenEdition}

\section{Journals}

Electronic version

URL: http://journals.openedition.org/samaj/6896

DOI: $10.4000 /$ samaj.6896

ISSN: 1960-6060

\section{Publisher}

Association pour la recherche sur l'Asie du Sud (ARAS)

Electronic reference

Loraine Kennedy, "Federalism as a Moderating Force? State-level Responses to India's New Citizenship Law", South Asia Multidisciplinary Academic Journal [Online], 24/25 | 2020, Online since 23 November 2020, connection on 15 December 2020. URL : http://journals.openedition.org/samaj/6896 ; DOI : https://doi.org/10.4000/samaj.6896

This text was automatically generated on 15 December 2020.

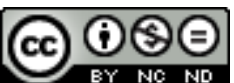

This work is licensed under a Creative Commons Attribution-NonCommercial-NoDerivatives 4.0 International License. 


\title{
Federalism as a Moderating Force? State-level Responses to India's New Citizenship Law
}

\author{
Loraine Kennedy
}

1 In the weeks and months following the Indian Parliament's adoption of the Citizenship Amendment Act 2019, a dozen states and Union Territories, and hundreds of local governments took a public stand to express their disapproval. Perhaps more importantly, states announced their refusal to comply with the law. Their opposition has taken various forms and mobilized different types of arguments-some decried the risks to the nation's social fabric, others questioned the law's constitutionality and appealed to the Supreme Court to intervene. Although less visible and impassioned than the widespread mobilization on the streets of the country, public reactions on the part of numerous states, Union territories and village councils are nonetheless deeply significant for several reasons. First, given that New Delhi is dependent on state governments to implement national laws on the ground, their refusal to cooperate represents a genuine risk to the central government's political agenda. Secondly, these assertions of subnational state power come at a time of increasing centralization under Bharatiya Janata Party (BJP) rule and thus need to be analyzed and interpreted against the wider backdrop of federal relations in India. Finally, to the extent this kind of "institutional" dissent is expressed through democratically elected bodies, it confers legitimacy on the process and opens up space that can potentially be leveraged as a moderating counterforce. It underscores the plasticity and inherent strength of the federal arrangement as a power sharing mechanism.

2 To discuss these matters, this contribution first briefly recalls the law and related measures at issue. It then describes the various expressions of dissent formulated by subnational governments, mapping the chronology and identifying the key arguments put forth. Finally, it situates these actions within the context of federal relations in India, relating several recent episodes that have exacerbated Centre-state tensions. 


\section{CAA, NRC, NPR: The legal and bureaucratic instruments at stake}

3 As critics have pointed out, the Citizenship Amendment Act (CAA), and related measures such as the National Register of Citizens and the National Population Register, mark a significant departure from India's specific brand of secularism, established at the time of independence. In matters governing the relationship between the state and citizens, the Constitution guarantees equality before the law (Article 14) and equality of citizenship, notably under Article 15(1), "The State shall not discriminate against any citizen on grounds only of religion, race, caste, sex, place of birth or any of them." Beyond formal provisions, the values that formed the foundation of Indian secularism marked an emphatic rejection of the idea that the nation be grounded in a particular religion, which was the basis of the "two nation theory" that justified the creation of Pakistan. It is this fundamental departure from time-bound principles-including the existential threat it represents-that was at the root of the many protests and sustained opposition across the country in late 2019 and early 2020.

The key elements of the amended Citizenship Act are well known and will only be very briefly described here as background for the remainder of the discussion. Simply stated, the law introduces religion as a criterion for determining who is eligible for citizenship. In particular, it proposes to not treat as "illegal migrants" certain categories of immigrants from Afghanistan, Bangladesh and Pakistan, where they were religious minorities, thereby opening up a path to citizenship for them. It explicitly lists the following communities: Hindu, Sikh, Buddhist, Jain, Parsi and Christian. Muslims are excluded from the list although, as is well documented, there are persecuted Muslim minorities in these countries. Fundamentally though, because the law does not include an avenue for citizenship for Muslim migrants, it puts at risk all Muslims who are unable to prove their nationality. The law has been denounced as explicitly leveled at Muslims with an aim to single them out for exclusion. Attempts by the government to refute this argument are undermined by the openly hostile rhetoric and violent actions targeting Muslims that have taken place with increasing frequency under BJP rule (see Ali Khan Mahmudabad's article in this special issue). ${ }^{1}$

5 The application of the new citizenship law relies on an administrative instrument, the National Register of Citizens (or NRC), to identify who will be counted as a citizen and who will be deemed an illegal migrant. The onus will be on individuals to prove with documentary evidence their citizenship claim, for instance their presence in the country before a particular date, their place of birth, and now also the place of birth of their parents (see below). ${ }^{2}$ The inability to provide the paper proof, or to convince authorities of the veracity of one's documents and claims, could result in Indian citizens and eligible migrants being stripped of their rights and rendered stateless.

The highly problematic nature of this exercise became unmistakably apparent when it was conducted in Assam. Even after a second round, intended to fix the problems encountered in a first round, almost two million people were unable to prove their citizenship, demonstrating the infeasibility of the approach. As scholars have emphasized, it is extremely difficult to produce documentary proof of one's civil status in India for various reasons, which include bureaucratic limitations as well as the precarious life circumstances of the majority of the population, which make conserving paper documents extremely difficult (see Mathur, this issue ${ }^{3}$ ). Even for relatively 
privileged Indians, securing these documents presents daunting challenges, for the underprivileged, the task is very often insurmountable. In light of the results from Assam, even supporters of the register were forced to admit the exercise was deeply flawed. ${ }^{4}$ Despite that, the Home Ministry announced in December 2019 that the NRC would be extended to the entire country before the 2024 Lok Sabha elections.

7 Another administrative instrument, the National Population Register (or NPR) has also come under fire. Although it is not new, its proposed utilization in the context of the CAA has brought it sharply into the crosshairs of protesters. It is grounded in the Citizenship Act 1955, the same law that was amended in 2019. An earlier amendment in 2003, under the Vajpayee-led BJP government, led to new rules being notified, which allowed for compulsory registration of citizens and the establishment of a National Register of Indian Citizens. ${ }^{5}$ The new rules enabled ground-level staff to flag cases of "doubtful" citizenship when compiling a list of all residents i.e., the Population Register. The NPR thus provides a legal and material basis for establishing the NRC, and it is in this sense that various scholars and organizations have opposed it, and asserted its inherent connection to NRC. ${ }^{6}$ Indeed, as we will see below, the NPR became embroiled in the anti-CAA protests because it was seen as a first step in creating the National Register of Citizens, an argument that the BJP government has refuted. It claims instead that it is part of the Census activity. Critics, however, contend this is incorrect because the rules governing the exercise derive from the Citizenship Act, specifically the 2003 Rules. Leaving aside the question of whether or not there is an intentional strategy to disguise the NRC as being part of the Census, confusion between the two arises from the fact that the central government has ordered the NPR to be updated, and that exercise will take place at the same time as the preparation for the 2021 Census exercise, notably the house listing phase. ${ }^{7}$

On the basis of the pilot schedules for the NPR that were canvassed in August 2019, it is understood that they include a question on where the respondent's parents were born. It also asked for Aadhaar details, ${ }^{8}$ driver's license, voter identity card and mobile number, although officially these questions would not be mandatory. This has raised alarm bells because if respondents share this information, it would "allow the Union government, for the first time, to connect their biometric details with information like the birthplace of their parents." 9

\section{Charting the timeline of subnational protest to CAA}

9 In the period immediately following the adoption of the new citizenship law in December 2019, numerous elected leaders across India spoke out, vowing not to implement the law within their territorial jurisdictions. Working on the basis of press reports and social media posts, it was possible to reconstruct a rough timeline of subnational state responses, which have varied in form, substance and intensity.

West Bengal was the first state to take official action to notify its unwillingness to cooperate with the central government's broader citizenship agenda. On Monday December 16, less than one week after the ratification of CAA, Mamata Banerjee's Trinamool Congress (TMC) government ordered a stay on all activities connected with updating the NPR in the state..$^{10}$ The decision, justified as being "in the interest of public order," was issued as widespread anti-CAA demonstrations rocked the state, including violent protests in some areas. 
11 A few weeks later, on December 31, Kerala became the first state to pass a formal resolution in the state assembly demanding that the CAA be repealed. ${ }^{11}$ Having been approved by all but one (BJP) MLA, the resolution was a strong declaration in a state where Muslims make up more than a quarter of the population. In an attempt to build momentum, the head of Kerala's Left Democratic Front government, Pinarayi Vijayan, wrote to the Chief Ministers of 11 other states proposing they join forces to oppose the CAA and urging them to pass a resolution..$^{12}$ The CPI(M)-led coalition then took a further step on January 14 by challenging the law as unconstitutional and filing a case with the Supreme Court (see below).

Following in rapid succession, other states passed resolutions in their state cabinets or assemblies. This was the case of two Congress-ruled states, Punjab on January 17 and Rajasthan on January 25. Beyond demanding the repeal of the CAA, Punjab's resolution also called for amendments to the questionnaire associated with the NPR process. ${ }^{13}$ These states were joined by TMC-ruled West Bengal, which passed a resolution on January 27. The cabinets of two other Congress-ruled states also issued resolutions, Chhattisgarh on January 30 and Madhya Pradesh on February 6. Moreover, it was reported that Chhattisgarh sought to de-notify an October 2019 order announcing the state's participation in the NPR exercise. ${ }^{14}$

On February 12, Puducherry became the first Union Territory (UT) to pass a resolution against the CAA, a significant development in light of the fact that UTs are administered directly from New Delhi. Indeed, the legality of passing such a resolution was questioned from some quarters, not least from the Lieutenant Governor Kiran Bedi, citing the bounded sovereignty allowed under the Government of Union Territories Act 1963. Bedi wrote to Chief Minister V. Narayanswamy to remind him that the law passed by Parliament "cannot be questioned or deliberated in any manner." 15 This was yet another episode in the ongoing power struggle between the BJP-appointed Lieutenant Governor and the Chief Minister over jurisdictional prerogatives between the executive and legislative branches. ${ }^{16}$ Significantly, the courts ruled in favor of the elected representatives, recognizing the primacy of their powers over the centrally appointed Lieutenant Governor. ${ }^{17}$ The central government's appeal to the Supreme Court to overturn the lower court's decision was dismissed, a case that some legal scholars considered a test of "the strength of Indian federalism in the Modi era." 18

14 The elected assembly of the National Capital Territory of Delhi (NCT Delhi), led by the Aam Aadmi Party, also passed a resolution on March 15, followed by Jharkhand. Although led by an alliance opposed to the BJP, Jharkhand's coalition government (Jharkhand Mukti Morcha-Congress-RJD) was one of the last to vote a resolution against the NRC and the NPR exercise on March 23, just one day before the start of the nationwide lockdown due to Covid-19. Protesters on the streets of Ranchi as well as other towns and villages had been demanding the Hemant Soren-led government to take a stand.

\section{Resistance also from within the National Democratic Alliance}

15 It is not surprising that states led by opposition parties were quick to mark their disagreement with the citizenship law and its attendant population and citizens' registers. Much more threatening for the central government was the fact that partners and allies in the National Democratic Alliance (NDA) ${ }^{19}$ also began to speak out. 
The first to do so was Bihar, ruled by the Janata Dal (United), whose legislative assembly unanimously passed a resolution declaring its refusal to implement the NRC, as well as the amended NPR. With an eye to the assembly elections scheduled for late 2020, Chief Minister Nitish Kumar specifically criticized the idea of respondents being asked about the date and birthplace of parents, ${ }^{20}$ underscoring the contentiousness of that specific point.

At the risk of rankling the BJP government in New Delhi, a number of other NDA states similarly publicly recorded their refusal to implement the NCR and NPR in their territories, even when they had voted the for the CAA in Parliament (see more on this below). Thus, in the case of Andhra Pradesh, officials stated that they would only agree to carry out the population register in its previous 2010 format. $^{21}$

One notable holdout among BJP allies was Tamil Nadu, where the AIADMK-led government withstood massive pressure to condemn the citizenship reforms as antiCAA protests swelled in size and number across the state in the first part of 2020. The civic unrest came on top of the ruling party's declining popularity-the party did not win a single seat in Lok Sabha elections and performed poorly in local body polls-, further stoking fears about the assembly polls scheduled in early 2021. Finally, after weeks of massive demonstrations, the State government raised its concerns about the NPR with the central government, requesting clarification and asking that some questions be removed. ${ }^{22}$ On March 12, claiming that the Centre had not provided the clarifications it sought, a minister in the E. Palaniswami-led government declared that it was putting the NPR on hold. ${ }^{23}$ However, it stopped short of passing an official resolution.

Odisha, ruled by the Biju Janata Dal (BJD) under the leadership of Naveen Patnaik since 2000 , is not technically a BJP ally but nonetheless supported the citizenship bill in Parliament. Although the Chief Minister told the press he did not support a nationwide NRC, he has not been willing to take a firm stand against the contentious issue. In general, the state's leadership has taken pains to distinguish state-level issues and electoral contests, where it sharply competes with the BJP, and national-level issues, where it has carefully avoided any friction with the central government (more below on this relationship).

In the case of Telangana, which extends issue-based support to the BJP national government, the ruling Telangana Rashtra Samithi (TRS) did not vote for the citizenship amendment bill in Parliament, reflecting its unwillingness to alienate Muslims in the state (approximately a fifth of the population) or jeopardize its strong alliance with the All India Majlis-e-Ittehad-ul-Muslimeen party (AIMIM), which has a very strong base in Hyderabad. On March 16, the state assembly passed a resolution opposing the trio CAA, NPR and NRC. ${ }^{24}$

20 As these 15 cases demonstrate, the behavior of state governments toward the citizenship reforms must be understood in terms of internal political calculations, which can include the timing of elections, as in Bihar, the magnitude of public unrest, as in Tamil Nadu, or pressure from regional coalition partners as in Telangana and Maharashtra. In Maharashtra, the Shiv Sena, a party with ideological positions broadly similar to the BJP but currently in a coalition government with the Congress and the Nationalist Congress Party, backpedaled in its support to the citizenship amendment bill. Although its 18 MPs voted for the bill in the Lok Sabha, two days later, bowing to strong pressure from Congress, its 3 MPs in the Rajya Sabha boycotted the vote, which 
nonetheless passed and became law on December $11 .{ }^{25}$ At the state-level, the leadership opined that there was no need for "a Bihar-like resolution in the Assembly." 26

Interestingly, Islak village in Maharashtra became the first local government to pass a resolution against CAA/NRC/NPR. Meeting on Republic Day (January 26, 2020), the gram panchayat (elected village council) took a pledge of non-cooperation, forwarding a signed document to the Ahmednagar district administration. According to press reports, the 2,000 strong village does not count any Muslims among its residents. The sarpanch (council president) is on record saying that the law had been opposed mainly on humanitarian grounds, and further, that most of the villagers, who are farmers, "neither have any document nor any piece of land to prove their existence." ${ }^{27} \mathrm{~A}$ month later, when a BJP-led municipality in Maharashtra passed a similar resolution, the council's chairperson was suspended by the party's state-level leadership for indiscipline. ${ }^{28}$

In other states too, local bodies mobilized in opposition to the citizenship law and registers, putting pressure on their state governments to take a stand. In Odisha, more than 400 gram panchayats located in 15 districts passed resolutions, and a memorandum was sent to the Chief Minister and the District Collectors. ${ }^{29}$ As noted above, Naveen Patnaik's government had supported the CAA and refrained from taking an official stance against New Delhi, even despite such grassroots demands.

\section{Mobilizing substantive and procedural arguments to oppose the law}

23 The dissent expressed on the part of India's subnational governments mobilized various types and combinations of arguments, both substantive and procedural. These included the risks to the nation's social fabric as a result of breaking with the country's secular heritage, the law's constitutionality, as well as the practical difficulties of implementing the law, notably with regard to the new questions contained in the NPR exercise.

Political leadership in the dissenting states did not hesitate to adopt extreme language to condemn what they considered extreme digressions from India's political culture. Thus, Punjab's Chief Minister Amarinder Singh, speaking in the state assembly, was quoted as saying: "This is exactly what happened in Germany in the 1930s. The Communists were targeted first and then Jews were killed. This is the time to speak up. Germans did not speak then, and they regretted it, but we have to speak now, so that we don't regret later." ${ }^{30}$ In this instance, the regional leader calls on the moral duty of governments and the Indian people to take a stand against the citizenship law, framed here as an existential threat. It is remarkable that the Shiromani Akali Dal (SAD), which is allied with the BJP and had voted in favor of the Citizenship Amendment Bill in Parliament, supported the resolution brought by the Congress-ruled Punjab government. SAD leader Bikram Majithi was recorded as saying, "If people have to stand in line and confirm where they were born, then we are against any legislation like this." ${ }^{31}$

It is perhaps not surprising to observe that states with strong Muslim minorities, like Kerala, West Bengal and Telangana, were especially sensitive to the threat posed by the law and took pains to pledge their commitment to protecting the community. ${ }^{32}$ In 
addition to condemning the discriminatory bias against Muslims contained in the law, a number of states have also underscored the social bias inherent in the conduct of the NPR exercise in particular, which would create tremendous hardship for vulnerable groups. In the letter that the Chief Minister of Chhattisgarh wrote to Narendra Modi to urge him to withdraw the CAA, he recalled the social profile of the state: “...a huge chunk of the state's population live below the poverty line, are landless and illiterate. They might surely face difficulties to accomplish the formalities as required by the Act." ${ }^{33}$

Likewise, villagers from a gram panchayat in Jharkhand who petitioned the Chief Minister to oppose CAA, specifically underscored the loss of time and money involved with trying to locate the documents. Importantly, they also stated their fears that government officials conducting the survey would seize the opportunity to exploit Adivasis. This reveals the deep mistrust that surrounds information-sharing with officials, whether directly linked to questions about citizenship or land holdings, and their apprehension that cooperation could leave them more vulnerable. It is not insignificant that this village was involved in the Pathalgadi movement, launched against the previous BJP-led state government to contest the dilution of laws designed to protect tribal land and prevent its transfer to the state or to non-tribals. ${ }^{34}$ Similarly, in the countless bastis (slums) in India's towns and cities, population surveys raise the specter of eviction. It is hardly unexpected then that ordinary people would regard the announcement of new enumeration exercises aimed at establishing identity and citizenship with mistrust and fear. The perspective of losing citizenship rights and being rendered stateless has driven people to the streets to protest and to pressure their state governments to reject the trio CAA/NRC/NPR.

With regard to legal arguments, Kerala's government has arguably gone the furthest by filing a case with the Supreme Court. The petition challenges the law under Article 131, the provision under which the Supreme Court has original jurisdiction to deal with any dispute between the Centre and a state. The suit challenges the validity of notifications issued in 2015 and 2016 under the Passport (Entry into India) Amendment Rules and the Foreigners (Amendment) Order, on grounds they are contrary to the Constitution. It further charges that there was no rationale nor any standard principles applied in grouping together Pakistan, Afghanistan and Bangladesh for the purpose of the CAA, and excluding neighboring countries like Sri Lanka, Myanmar, Nepal and Bhutan, from which there has also been trans-border migration. Finally, the suit also claims that the CAA violates the Constitution by going against the fundamental principle of secularism "which has been recognized repeatedly by this Honourable Court as a basic structure of the Constitution." ${ }^{35}$ Defending his state's action, Chief Minister Pinarayi Vijayan condemned the CAA for disregarding the country's religious and linguistic diversities. $\mathrm{He}$ is on record saying that the new law was "part of a larger agenda... against the Muslim community." ${ }^{36}$ The CPI(M)-led government's suit asserts that the law violates Article 14 (Equality before law), Article 21 (Protection of life and personal liberty) and Article 25 (Freedom of conscience and free profession, practice, and propagation of religion). Two months after Kerala, Congress-ruled Rajasthan also filed a similar suit in the Supreme Court, also under Article 131. Both cases call on the country's highest court to declare the citizenship law unconstitutional.

28 Legal experts and other observers have remarked that the constitutional challenge has a very limited chance of succeeding. On one hand, the Seventh Schedule of the 
Constitution clearly designates citizenship and related issues, including naturalization, as "Union" subjects, i.e., under the exclusive jurisdiction of the Union government. On the other, states are legally bound under Article 256 to implement laws made in Parliament. Members of the central government spoke out to condemn Kerala's appeal against the law, both the suit and the resolution, with one BJP Rajya Sabha MP calling for contempt proceedings against Chief Minister Vijayan. ${ }^{37}$ Even senior Congress leaders Kapil Sibal and Shashi Tharoor are on record saying that states do not have legal grounds for refusing to implement the CAA, as it is a national law. ${ }^{38}$

Nonetheless, this appeal to the Supreme Court is a bold move and offers a stirring parallel with anti-CAA protesters brandishing a copy of the Constitution of India in their hands or reciting it in public. Here, states are basing their argument for the case to be heard on an earlier judgment (State of Karnataka v Union of India, 1978), in which it was decided that to invoke Article 131, states need not show their rights had been violated only that their charge involves a legal question. ${ }^{39}$

It should be noted that dozens of other petitions were filed against the law in the Supreme Court by organizations and prominent political leaders. ${ }^{40}$ Most of these come under Article 32, which gives citizens the right to approach the Supreme Court when their fundamental rights are violated. Only individuals can claim Fundamental Rights, not state governments. Commenting on these petitions, scholars have argued that the law appears to effectively contravene Fundamental Rights, for instance Article 15, which prohibits discrimination on the basis of religion. Yet, despite this apparently flagrant violation, the new citizenship law and the NRC put religion at their core. As Niraja Gopal Jayal (2019b) argues:

(...) faith is set to become the exclusive criterion for determining who is an Indian citizen and who is not, for inclusion as well as for exclusion. Together, the NRC and the CAB [Citizenship Amendment Bill] have the potential of transforming India into a majoritarian polity with gradations of citizenship rights that undermine the constitutional principle of universal equal citizenship; with privileges of inclusion being attached to some categories of citizens while others suffer the disabilities of exclusion.

\section{Realpolitik / power struggles}

31 Apart from ideals of equality before the law and other fundamental rights, the protest actions taken by state governments demonstrate a practical understanding of Centrestate relations. The Union government is dependent on the states to implement the citizenship law and to carry out the surveys on which it will rely. It is estimated that as many as 3 million enumerators will be needed ${ }^{41}$ to undertake the first stages for NPR and the Census, and it is the state-level administrations that arrange for these enumerators. Thus, in passing resolutions and making public statements committing to not undertake NPR/NCR, states are openly defying the central government. There have been indications that the central government is indeed worried about the prospect of non-cooperation. Speaking in the Lok Sabha in early March, just a few weeks before the surveys were scheduled to start (April 1), the Union Minister of State for Home said the government was in talks with those states "having concerns in regard to the preparation of NPR." ${ }^{42}$ It is unclear how these negotiations would have ultimately played out because the survey exercise was postponed due to the Covid-19 pandemic. 
Realpolitik also shapes the way the central government plays the federal game, as it uses the multiple instruments at its disposal as carrots or sticks to attain its goals and keep regional leaders in line. New Delhi can threaten to withhold critical financial assistance from state governments that do not cooperate or conversely, to reward those who do. This was reportedly the case of the BJD-led government in Odisha, where the state received massive funds from the Centre as a result of its support for the Citizenship Amendment Bill in Parliament. ${ }^{43}$ As noted above, although in tight competition with the BJP at the state-level and despite pressure from popular protests, Naveen Patnaik's government did not pass a resolution against CAA. According to one journalist:

(...) it is now clear that the BJD's support for CAA was a political trade-off aimed at bailing the state out of a tight economic situation. Reliable sources say that with revenue generation from different sources, especially the mining sector - the biggest contributor to the exchequer - not being satisfactory, the government is struggling to keep many of its welfare schemes going. It needs generous assistance from the Centre, not only to keep these schemes going, but also to compensate for the losses sustained in cyclones like Fani which had hit the state in May this year. ${ }^{44}$

Federal relations have always been about tug and pull, whether because of financial tensions-state governments are structurally dependent on the Centre-or because of political differences, as when state and central governments are headed by different parties or coalitions. Currently, the BJP's absolute majority in the Lok Sabha strongly conditions Centre-state relations, and this backdrop must be kept in mind when analyzing the recent manifestations of dissent.

\section{Situating state-level protest within federal relations}

33 Although the word "federal" does not appear in India's Constitution, federal principles are nonetheless fundamental to the functioning of India's parliamentary democracy. Federalism has deepened over the decades since independence as the territories of the different states have become increasingly salient as discrete political spaces. ${ }^{45}$ The delinking of political support in state- and national-level elections, i.e., voters supporting different parties in assembly and parliamentary elections, reflects the relative autonomy of these two political arenas. ${ }^{46}$ This territorialization process has been gradual, starting with the reorganization of state boundaries along linguistic lines in the 1950 s and 60 s, followed by the development of state-level political formations, whether branches of national parties acting de facto as a distinct organization or regional parties, ${ }^{47}$ and the end of the one-dominant party system. Because federal relations are fundamentally political, they are shaped by these broader changes in India's party system. Thus, after a period of centralized power, especially under Indira Gandhi's long rule, federal relations gradually became more balanced in the 1990s, reflecting both political changes, and the indirect impacts of economic reforms, which led to greater policy space on the part of states (Kennedy 2018). State-based parties emerged on the national scene as key players, even "kingmakers" via their membership in larger coalitions, the NDA and the UPA (United Progressive Alliance, Congress-led, in power from 2004 until 2014). They gained valuable experience by participating in national governments and policy-making, and critically, as Louise Tillin (2017) reminds 
us, the presence of regional parties in national coalitions "helped to establish checks on the arbitrary use of central power" (P. 7).

That period, which lasted for roughly 25 years, came to an end in 2014 when the BJP won a majority of seats in the parliamentary election, a performance repeated in 2019 with an even stronger majority. In this context, the support of regional powers is no longer needed to stay in power, and the central government has not felt compelled to build coalitions of support among state-level leadership for national policies, as the CAA illustrates. Indeed, there is ample evidence that the BJP leadership is challenging the status quo in federal relations, as it attempts to concentrate power at the top (Aiyar and Tillin 2020). In the absence of institutionalized change, it has "slipped back into the old mode" of the pre-coalition era (Arora and Kailash 2018:300).

Efforts to centralize can be observed in various ways: strengthening the functioning of key national institutions ${ }^{48}$ bypassing structures of government at different levels to appeal directly to groups in the electorate, imposing policies on national territory without prior consultation, as well as implementing reforms on sensitive issues such as a national language (imposition of Hindi), ${ }^{49}$ and now citizenship. Such actions have been detrimental to federal relations, generating resentment among both oppositionled and politically friendly states. Two examples can be cited to illustrate this broader trend: the reform of taxes on goods and services and the introduction of conditionalities in financial relations between the Centre and the states. ${ }^{50}$

The reform of the Goods and Services Tax (GST), long on the agenda, was ratified in 2016 as the $101^{\text {st }}$ Constitutional Amendment. By establishing uniform rates across the country, it was designed to lift barriers to inter-state trade. Although based on sound principles, for which there was broad agreement, the specific features of the reform and especially its practical application have led to much acrimony between state governments and New Delhi, feelings which have become increasingly bitter in recent months. The reform introduced a fundamental change in fiscal federal relations insofar as it put in place a framework for sharing tax powers, whereas the Constitution had clearly separated taxation powers between the Union and the states. Critics argue that such "shared sovereignty" is detrimental to the states as it removes a major item (sales tax), as well as other indirect taxes, from their sole jurisdiction. Concretely, by introducing uniform rates across the national territory, states no longer have the ability to adjust the tax rate when they choose, e.g., in response to contingencies or to finance a new flagship initiative.

The GST Council, the governance structure put in place as part of this reform, has only served to aggravate the criticism by giving the Centre disproportionate powers. In effect, the central government's vote is weighted to correspond to one-third of the total vote, while all states' combined votes count for two-thirds. Each decision taken by the Council must be supported by at least 75 per cent of the weighted votes of the members present. In essence, this means that without New Delhi's support no resolution can be passed; the central government has a de facto veto. The BJP government has defended the structure of the Council as conducive to greater cooperation because if New Delhi wants to endorse a decision, it needs the support of at least 19 states, and conversely, if states want to override the Centre's proposals, they must also act in coordination. The arrangement gives the same voice to each state regardless of its size or contribution to tax revenues, and whereas this makes it possible to claim theoretical and formal equality, it appears somewhat removed from 
the geopolitical reality of recent decades, characterized by a divergence in the trajectories of the states. Given both the very different situations of states, and the disproportionate powers the governance structure gives to the Centre, it is not surprising that it has come under fire.

However, the most controversial aspect about the GST reform pertains to the compensation to be paid to the states to make up for lost fiscal revenue. The agreement on which the states signed off projected a growth in revenues of 14 percent per year (based on 2015-2016 collections) and made provisions to compensate states if their actual collections fell short of that. However, compensation has not been paid in a timely manner and payments are often pending for months at a time. Significantly, as the anti-CAA mobilization was getting underway in the country, states, which had not received relief to offset their dwindling resources, became increasingly vocal in reminding New Delhi of its commitment. Tensions have further risen as the impacts from the Covid-19 pandemic and the lockdown have strained state finances. ${ }^{51}$

The second example also touches on financial relations and has to do with the way resources are distributed between states. It underscores the increasing tendency of the central government to impose conditionalities on states, a feature that also resonates with competitive federalism, wherein states are required to compete with each other for resources.

Shortly after coming to power in 2014, the Modi government dissolved the Planning Commission, established by Nehru in 1950, and replaced it with the NITI (National Institution for Transforming India) Aayog. A key justification was to put an end to discretionary financial transfers. Instead, the Finance Commission alone would arbitrate on the distribution of tax revenues between the Centre and the states and among the different states. Appointed every five years by the Union government, the Finance Commission elaborates a resource-sharing formula, taking into consideration a number of objective criteria such as per capita income, population and surface area of the states. In the terms of reference given to the $15^{\text {th }}$ Finance Commission, appointed by the BJP government, it was proposed that population data from the 2011 census serve as the basis for recommendations, as opposed to the 1971 census, which was the main source used by previous commissions. The decision to use 2011 data would result in a greater share of resources for states in the Hindi heartland, whose population growth has been significantly higher than in some other regions, especially South India. Defended by Modi's government as necessary to meet current needs, this recommendation was viewed by its detractors as motivated by partisan political calculations, breaking with the neutrality of the Finance Commission. It was hotly contested, most notably by the states likely to suffer a relative decline in their allocations, incensed at what amounted to a punishment for having controlled their birth rates. A number of states joined together to protest the measure, initially Kerala, Karnataka and Andhra Pradesh, later joined by West Bengal, Punjab and Delhi.

41 In its interim report, issued in February 2020, the Finance Commission demonstrated its autonomy from the central government by adopting a revenue-sharing formula that diluted the weight given to the 2011 census and added the criterion "demographic performance," recognizing efforts in population control as well as human capital outcomes related to investments in education and health. Celebrated as the proof that collective action undertaken by the states had been successful, this decision was also 
interpreted by some observers as taking into account the strained federal relations as a result of GST..$^{52}$

Apart from this point, much broader criticism has been leveled against the BJP government for what is perceived as the politicization of fiscal transfers, in particular the attempt to forcibly impose its policy agenda by conditioning transfers and borrowing rights on states' adherence to that agenda. For example, the terms of reference for the $15^{\text {th }}$ Finance Commission contain the recommendation that "measurable performance-based incentives" be used, including taking into consideration "achievements in implementation of flagship schemes of Government of India." ${ }^{53}$ This recommendation has been perceived as tantamount to introducing conditionalities in the allocation of transfers that are intended to be unconditional, i.e., spent as per the wishes of the state governments..$^{54}$ Interestingly, here too, the Finance Commission does not appear to be overly inclined to follow it. ${ }^{55}$

The generalization of performance criteria embodies New Delhi's desire to dominate and discipline the states, under the pretext that they are not responsible enough. If the accusation of fiscal laxity was justified in the past, it is now less and less confirmed in practice. ${ }^{56}$ The laws imposing fiscal and budgetary responsibility, adopted throughout the 2000s, have produced their effects. A more recent example of this patronizing attitude transpired mid-2020 in the midst of the states' battle to contain and alleviate the effects of the Covid-19 pandemic.

4 At a moment when states were desperately in need of support and were expecting a grant from the Centre, the government announced instead that states would be allowed additional borrowing rights on the market, an additional 2 percent beyond the limit of 3 percent of state GDP. However, apart from an unconditional increase of 0.5 percent, strings were attached for further borrowing, tied to implementing four central government policy priorities. ${ }^{57}$ These included the "One Nation, One Ration Card" scheme, linking Aadhaar with ration cards; business-friendly measures, including the automatic renewal of industrial and commercial licenses; power sector reforms aimed at reducing losses; and reforms designed to increase revenue for urban local bodies, e.g., notifying property taxes and introducing water and sewerage charges.

Although even critics recognize that some of these reforms may have welcome outcomes, like allowing migrants to access fair price shops under the One Card scheme, the conditionality dimension has generated anger and frustration on the part of state governments. Many commentators question whether this will set a precedent for future borrowing rights. According to M. Govinda Rao (2020), a specialist of fiscal federalism and member of the previous $\left(14^{\text {th }}\right)$ Finance Commission, this is the first time in independent India's history that the Union government has put conditions on the market borrowings of the states. He recalls, as a point of comparison, that states were allowed to increase borrowing by 1.5 percent in 2008 in the aftermath of the global financial crisis, without any conditions. Many critics were particularly irritated about the context and timing of the decision. In the words of Kerala's finance minister, saying out loud what many observers were thinking, "[the] Centre has used the pandemic crisis to introduce conditions on states' market borrowings." ${ }^{58}$ 


\section{Federalism as a moderating force?}

Cive not cooperative federalism would appear to be taking hold, a tendency that the current pandemic has only served to exacerbate. In the face of resistance to CAA on the part of states, the central government has brandished the constitutional stick, Article 256, the provision that directs states to ensure compliance with the laws made by Parliament. However, dissenting state governments have countered by asserting their constitutional duty to defend secularism and pluralism. often taking the cue from their own mobilized citizens, state governments are proclaiming the values they are ready to defend, notably secularism and the fundamental rights contained in the Constitution, thereby asserting their right to stand up and be heard as distinct and sovereign entities within the Indian Union. Although the BJP enjoys an absolute majority in Parliament, state-level political parties and their leaders are not willing to submit obediently to central authority, reverting as it were to India's early days of oneparty dominance. After decades during which states have emerged as increasingly autonomous political arenas, and key players economically, regional politics and party systems have become a force to reckon with. As one scholar observed, with regard to the Kerala Assembly's anti-CAA resolution, "The Kerala legislature is not engaged in constitutional legalities. Rather, it is trading in constitutional politics: assessing the CAA, assembling a reservoir of arguments against it and asserting the state's idea of India" (Dam 2020, italics added).

What is arguably so powerful about the states' (and gram panchayats') open expressions of dissent against the new citizenship laws: they convey the belief that India's democratic system guarantees space for the people and their elected representatives to contradict and defy laws that go against their "idea" of India. The sheer scale of the state-level opposition to CAA/NPR/NRC confers weight to the collective action, allowing dissenting states to form a counterbalance to New Delhi. 
Thus, when added to the realpolitik dimension, notably the fact that state government cooperation is essential for conducting the survey exercises required for establishing the NRC, the federal framework can be seen to operate as a moderating force against a political agenda that threatens the unity of the nation.

\section{BIBLIOGRAPHY}

Aiyar, Yamini and Louise Tillin. 2020. “'One Nation,' BJP, and the Future of Indian Federalism.” India Review 19(2):117-35.

Arora, Balveer and K. K. Kailash. 2018. "Beyond Quasi Federalism: Change and Continuity in Indian Federalism." Studies in Indian Politics 6(2):297-302.

Banerjee, Mukulika and Manisha Priyam. 2020. "Margins and Marginality: The Pathalgadi Movement and Jharkhand Elections 2019." The India Forum June 5. Retrieved October 15, 2020 https://www.theindiaforum.in/article/margins-and-marginality

Bhargava, Rajeev. 2006. “The Distinctiveness of Indian Secularism.” Pp. 20-58 in The Future of Secularism, edited by T. Srinivasan. Delhi: Oxford University Press.

Dam, Shubhankar. 2020. "Untied States: The Contours of the Federal Showdown over the CAA and NRC.” The Caravan, January 30. Retrieved October 15, 2020 (https://caravanmagazine.in/politics/ contours-federal-showdown-caa-nrc).

Jayal, Niraja Gopal. 2019a. "Reconfiguring Citizenship in Contemporary India.” South Asia: Journal of South Asian Studies 42(1):33-50.

Jayal, Niraja Gopal. 2019b. "Faith Based Citizenship." The India Forum, Nov. 1. Retrieved October 15, 2020 (https://www.theindiaforum.in/sites/default/files/pdf/2019/11/01/faith-basedcitizenship.pdf).

Kennedy, Loraine. 2014. The Politics of Economic Restructuring in India. Economic Governance and State Spatial Rescaling. Abingdon; New York: Routledge.

Kennedy, Loraine. 2018. Le fédéralisme indien: un système en négociation constante. Pp. 33-60 in L'Inde contemporaine, edited by C. Jaffrelot. Paris: Fayard/Pluriel.

Pai, Sudha. 1990. "Regional Parties and the Emerging Pattern of Politics in India." The Indian Journal of Political Science 51(3):393-415.

Rao, M. Govinda. 2020. "States' Loss of Fiscal Autonomy in a Centralised Federal System." The India Forum, June 5. Retrieved October 15, 2020 https://www.theindiaforum.in/article/statesloss-fiscal-autonomy-centralised-federal-system

Sriraman, Tarangini. 2018. In Pursuit of Proof: A History of Identification Documents in India. New Delhi: Oxford University Press.

Tillin, Louise. 2017. “India's Democracy at 70: The Federalist Compromise." Journal of Democracy 28(3):64-75. 
Yadav, Yogendra and Suhas Palshikar. 2008. "Ten Theses on State Politics in India." Seminar November 591:14-22.

Yadav, Yogendra and Suhas Palshikar. 2009. "Principal State Level Contests and Derivative National Choices: Electoral Trends in 2004-09." Economic and Political Weekly 44(6):55-62.

\section{NOTES}

1. https://journals.openedition.org/samaj/6701

2. For issues surrounding paper proof, see Tarangini Sriraman's recent book, In Pursuit of Proof: A History of Identification Documents in India (2018). A review of the book is available in this journal: https://journals.openedition.org/samaj/6222

3. http://journals.openedition.org/samaj/6917

4. See Dutta, Rajib. 2020. "NRC is Flawed, Won't Accept in Present Form: Assam CM Sarbananda Sonowal," Times of India, October 12. Retrieved on November 22, 2020 (https:// timesofindia.indiatimes.com/city/guwahati/nrc-is-flawed-wont-accept-in-present-form-assamcm-sarbananda-sonowal/articleshow/78612627.cms).

5. See Citizenship (Registration of Citizens and Issue of National Identity Cards) Rules, 2003, available at: https://censusindia.gov.in/2011-Act\&Rules/notifications/citizenship_rules2003.pdf 6. See, for instance, Jayal (2019a, 2019b). See also Daniya, Shoaib. 2019. "Scroll Investigation: Amit Shah's all-India NRC Has already Begun-With the NPR." Scroll.in, December 17. Retrieved on November 22, 2020 (https://scroll.in/article/947116/scroll-investigation-amit-shahs-all-indianrc-has-already-begun-with-the-npr).

7. See PTI Staff. 2019. "Top officials discuss strategy to carry out census exercise." Press Trust of India, October 17. Retrieved on November 22, 2020 (http://www.ptinews.com/news/ 10910384_Top-officials-discuss-strategy-to-carry-out-census-exercise).

8. Aadhaar is the name of India's identification program, which uses biometric data to establish unique identity cards. It was the focus of a recent special issue of SAMAJ, "Unique Identification in India: Aadhaar, Biometrics and Technology-Mediated Identities" available at: https://doi.org/ 10.4000/samaj.6277

9. See Daniya, Shoaib. 2019. "Scroll Investigation: Amit Shah's all-India NRC Has already BegunWith the NPR.” Scroll.in, December 17. Retrieved on November 22, 2020 (https://scroll.in/article/ 947116/scroll-investigation-amit-shahs-all-india-nrc-has-already-begun-with-the-npr).

10. See Scroll Staff. 2019. "Mamata Banerjee Stays all Work Related to NPR Amid Protests over Citizenship Law.” Scroll.in, December 17. Retrieved on November 22, 2020 (https://scroll.in/ latest/947064/mamata-banerjee-stays-all-work-related-to-npr-amid-protests-over-citizenshiplaw). 11. See Express News Service. 2020. "Kerala vs Centre: Faceoff after House Resolution on CAA." Indian Express, January 1. Retrieved on November 22, 2020 (https://indianexpress.com/article/ india/kerala-house-caa-resolution-p-vijayan-6193984/).

12. According to press reports, these were: Jharkhand, West Bengal, Delhi, Maharashtra, Bihar, Puducherry, Madhya Pradesh, Rajasthan, Punjab, Andhra Pradesh and Odisha, see Special Correspondent. 2020. "Kerala Chief Minister Pinarayi Vijayan writes to 11 CMs on Citizenship Amendment Act," The Hindu, January 3. Retrieved on November 22, 2020 (https:// www.thehindu.com/news/national/kerala/kerala-cm-writes-to-11-chief-ministers-oncitizenship-amendment-act/article30471209.ece).

13. See Chhina, Man Aman Singh. 2020."Punjab Assembly Goes a Step beyond Kerala: Scrap CAA, Change NPR forms.” Indian Express, January 18. Retrieved on November 22, 2020 (https:// 
indianexpress.com/article/india/punjab-assembly-goes-a-step-beyond-kerala-scrap-caa-changenpr-forms-6222205/2

14. See Chhina, Man Aman Singh, and Manoj C G. 2020. "CAA: After Kerala, Punjab Govt will Seek House Rejection Today." Indian Express, January 17. Retrieved on November 22, 2020 (https:// indianexpress.com/article/india/caa-after-kerala-punjab-govt-will-seek-house-rejectiontoday-6220638/).

15. See Scroll Staff. 2020. "Citizenship Act: Puducherry Becomes first Union Territory to Pass Resolution against the Law," Scroll.in, February 12. Retrieved on November 22 (https://scroll.in/ latest/952908/citizenship-act-puducherry-becomes-first-union-territory-to-pass-resolutionagainst-the-law).

16. See Legal Correspondent. 2019."Puducherry Turf War: Kiran Bedi Asked to Move Division Bench First.” The Hindu, July 12. Retrieved on November 22, 2020 (https://www.thehindu.com/ news/cities/puducherry/puducherry-turf-war-kiran-bedi-asked-to-move-division-bench-first/ article28415644.ece).

17. The judgment of the Madras High Court dated April 30, 2020 states "[Article 239A] symbolizes the supremacy of the Legislature above the Administrator in the case of the Union Territory of Puducherry..." The documents related to the case are available online, see Supreme Court Observer, Case No. SLP (C)12072/2019. Retrieved on October 22, 2020 (https:// www.scobserver.in/court-case/administrative-head-of-puducherry).

18. See Mathew Idiculla's (2019) opinion piece on this ruling, "The Primacy of the Elected," The Hindu, July 4. Retrieved on November 22, 2020 (https://www.thehindu.com/opinion/op-ed/theprimacy-of-the-elected/article28275565.ece). For a summary of the case brought before the Supreme Court (Union of India v. K Lakshminarayanan), see: https://www.scobserver.in/courtcase/administrative-head-of-puducherry (Retrieved on October 15, 2020).

19. NDA is a coalition of political parties formed in 1998 with BJP as its largest and most influential component. Its current membership is 19 parties, most of which are small, regionalbased organizations.

20. See Singh, Santosh. 2020."Nitish Kumar: Will Urge Govt to Drop NPR Questions on parents' Birth.” Indian Express, January 29. Retrieved on November 22, 2020 (https://indianexpress.com/ article/india/nitish-kumar-will-urge-govt-to-drop-npr-questions-on-parents-birth-6240187/).

21. The Chief Minister spoke out against the NRC and NPR as early as December 2019, and the Cabinet opposed it at a meeting in early March. However, the state assembly did not pass a resolution to that effect until June 2020. See Raghavendra, V. 2020. "Andhra Pradesh Assembly Passes Resolution against NRC and NPR." The Hindu, June 17. Retrieved on November 22, 2020 (https://www.thehindu.com/news/national/andhra-pradesh/assembly-passes-resolutionagainst-nrc-and-npr/article31854935.ece).

22. See Sivapriyan, E.T.B. 2020. "Anti-CAA Protests: Tamil Nadu Government Holds Talks with Centre." Deccan Herald, March 3. Retrieved on November 22, 2020 (https:// www.deccanherald.com/national/south/anti-caa-protests-tamil-nadu-government-holds-talkswith-centre-809975.html).

23. See Stalin, J. Sam Daniel. 2020.“BJP Ally AIADMK Puts National Population Register on Hold in Tamil Nadu." NDTV, March 3. Retrieved on November 22, 2020 (https://www.ndtv.com/indianews/bjp-ally-aiadmk-puts-national-population-register-on-hold-in-tamil-nadu-2193967).

24. See Rajeev. M. 2020. “TS Assembly Passes Resolution against CAA, NPR, and NRC." The Hindu, March 16. Retrieved on November 22, 2020 (https://www.thehindu.com/news/national/ telangana/telangana-assembly-passes-resolution-opposing-caa-npr-and-nrc/ article31081955.ece).

25. See Express News Service. 2019.“Two Days after It Voted for Citizenship Amendment Bill in LS, Sena Walks Out of RS." Indian Express, December 12. Retrieved on November 22, 2020 (https:// 
indianexpress.com/article/india/two-days-after-it-voted-for-citizenship-amendment-bill-in-lssena-walks-out-of-rs-6162610/).

26. See Express News Service. 2020. "Maharashtra Unlikely to Pass Resolution against CAA-NRCNPR," Says Ajit Pawar, Indian Express, March 2. Retrieved on November 22, 2020 (https:// indianexpress.com/article/cities/mumbai/house-unlikely-to-pass-resolution-against-caa-nrcnpr-says-ajit-pawar-6294623/2.

27. See Akhef, Mohammed. 2020."Maharashtra Village is India's First to Pass Resolution Against CAA, NRC." Times of India, February 3. Retrieved on November 22, 2020 (https:// timesofindia.indiatimes.com/city/aurangabad/ahmednagar-village-first-in-india-to-passresolution-against-caa-nrc/articleshow/73887453.cms).

28. See PTI. 2020."Maharashtra BJP Suspends 2 Local Body Leaders for Anti-CAA Stand.” The Wire, March 4. Retrieved on November 22, 2020 (https://thewire.in/politics/bjp-suspends-leadersanti-caa).

29. See Staff Reporter. 2020. "Gram Sabhas in 15 Odisha Districts Pass Resolutions Against NPR, NRC, CAA," The Hindu, March 17. Retrieved on November 22, 2020 (https://www.thehindu.com/ news/national/other-states/gram-sabhas-in-15-odisha-districts-pass-resolutions-against-nprnrc-caa/article31087276.ece).

30. See Chhina, Man Aman Singh. 2020. "Punjab Assembly Goes a step Beyond Kerala: Scrap CAA, Change NPR forms." Indian Express, January 18. Retrieved on November 22, 2020 (https:// indianexpress.com/article/india/punjab-assembly-goes-a-step-beyond-kerala-scrap-caa-changenpr-forms-6222205/L.

31. See Express Web Desk. 2020."Amarinder on CAA: What Happened under Hitler is Unfolding in India now," Indian Express, January 18. Retrieved on November 22, 2020 (https:// indianexpress.com/article/india/punjab-assembly-session-business-bill-congress-aap-bjpsad-6221164/).

32. Jammu and Kashmir, with the highest percentage of Muslims according to the 2011 Census (68 percent), does not currently have an elected assembly. Its administrative status was changed from a state to two Union Territories in August 2019, when the BJP government abrogated the state's special status granted under Article 370 of the Constitution.

33. See Kaiser, Ejaz. 2020. "Chhattisgarh Cabinet Passes Resolution against CAA, Urges PM to Withdraw It." The New Indian Express, January 30. Retrieved on November 22, 2020 (https:// www.newindianexpress.com/nation/2020/jan/30/chhattisgarh-cabinet-passes-resolutionagainst-caa-urges-pm-to-withdraw-it-2096681.html).

34. On the Pathalgadi movement in Jharkhand, see Banerjee and Priyam (2020).

35. The original suit can be accessed at Supreme Court Observer. https://www.scobserver.in/ court-case/kerala-caa-suit (Retrieved on Oct. 20, 2020).

36. See Express News Service. 2020. "Kerala vs Centre: Faceoff after House Resolution on CAA." Indian Express, January 1. Retrieved on November 22, 2020 (https://indianexpress.com/article/ india/kerala-house-caa-resolution-p-vijayan-6193984/2

37. See Express News Service. 2020. "Kerala vs Centre: Faceoff after House Resolution on CAA." Indian Express, January 1. Retrieved on November 22, 2020 (https://indianexpress.com/article/ india/kerala-house-caa-resolution-p-vijayan-6193984/)

38. See Scroll Staff. 2020."Anti-CAA Resolutions Passed by States are a Political Gesture, Says Shashi Tharoor," Scroll.in, January 23. Retrieved on November 22, 2020 (https://scroll.in/latest/ 950852/anti-caa-resolutions-passed-by-states-are-a-political-gesture-says-shashi-tharoor ).

39. See Vishwanath, Apurva. 2020."Explained: Centre-state disputes and Article 131." Indian Express, January 16. Retrieved on November 22, 2020. https://indianexpress.com/article/ explained/explained-article-131-on-which-kerala-has-based-its-challenge-to-the-caa-6216611/

40. These include for instance, Congress leader Jairam Ramesh, RJD leader Manoj Jha, Trinamool Congress MP Mahua Moitra and AIMIM leader Asaduddin Owaisi. 
41. See Chandrashekhar, Vaishnavi. 2020."Unrest over Citizenship Policies could Imperil India's Census." Science, March 17. Retrieved on November 22, 2020 (https://www.sciencemag.org/news/ 2020/03/unrest-over-citizenship-policies-could-imperil-indias-census).

42. See Special Correspondent. 2020."Centre in Talk with States Wary of NPR," The Hindu, March 3. Retrieved on November 22, 2020 (https://www.thehindu.com/news/national/centre-in-talkswith-states-wary-of-npr/article30975434.ece).

43. The press has reported that the BJD leader is also implicated in a scam case currently under investigation by the CBI, which would provide additional motivation to cultivate good relations with the central government. See Mishra, Ashutosh. 2019. "Odisha: Why Naveen Patnaik Abandoned Policy of Equidistance and Supported CAA." The Wire, December 16. Retrieved on November 22, 2020 (https://thewire.in/government/cab-odisha-naveen-patnaik-citizenship-act). 44. See Mishra, Ashutosh. 2019. "Odisha: Why Naveen Patnaik Abandoned Policy of Equidistance and Supported CAA," The Wire, December 16. Retrieved on November 22, 2020 (https:// thewire.in/government/cab-odisha-naveen-patnaik-citizenship-act).

45. See, for instance, Yadav and Palshikar (2008) and Kennedy (2014).

46. Yadav and Palshikar (2009) argue that state-level contests have become "principal" and national-level contests "derivative." In other words, voter choices are "shaped and filtered" by state-level politics.

47. Sudha Pai provides this definition of regional parties: “(...) parties restricted to a particular state and rooted in both regional aspirations and grievances. The support base of the party is limited to a particular state because it identifies itself with the region's culture, language, religion etc." (Pai 1990:393).

48. One example is the NITI Aayog, discussed more below. See also Aiyar and Tillin (2020).

49. See the piece by Anandhi, S. and M. Vijayabaskar. 2017. "Making Sense of Tamil Nadu's AntiHindi Protests," The Wire, July 11. Retrieved on November 22, 2020 (https://thewire.in/politics/ tamil-nadu-anti-hindi-protests).

50. This section draws on Kennedy (2018).

51. In October 2020, as this piece was being finalized, the Union finance minister gave assurances to the states that compensation would be paid in full. See Prasad, Gireesh Chandra. 2020. "Centre Calls Truce with States on GST." Mint, October 6. Retrieved on November 22, 2020 (https:// www.livemint.com/news/india/centre-calls-truce-with-states-on-gst-11601944501139.html).

52. See, for instance, Editor. 2020. "Cognisant of Constraints: On $15^{\text {th }}$ Finance Commission's Interim Report." The Hindu, February 3. Retrieved on November 22, 2020 (https:// www.thehindu.com/opinion/editorial/cognisant-of-constraints/article30721001.ece).

53. The terms of reference are available on the Finance Commission website: fincomindia.nic.in last accessed October 29, 2020.

54. Other Finance Commissions introduced incentives to encourage practices, but they were restricted to three areas: fiscal responsibility, population control, and devolution of funds to local governments.

55. It is not mentioned in their first report covering 2020-2021.

56. See Jain, Dipti. 2018."Why $15^{\text {th }}$ Finance Commission should Provide States Greater Resources, Autonomy." Mint, June 8. Retrieved on November 22, 2020 (https://www.livemint.com/Politics/ pVE6WL91vTqjpq02lTBKuK/Why-15th-Finance-Commission-should-provide-states-greaterre.html\#box_1542031649945).

57. See Sahu, Prasanta. 2020."Why States are Not Liking Centre's Extra Borrowing Limit Conditions," Financial Express, May 19. Retrieved on November 22, 2020 (https:// www.financialexpress.com/economy/covid19-economic-package-why-states-are-not-likingcentres-extra-borrowing-limit-conditions/1963137/).

58. Cited by Surojit Gupta and Siddharth Chatterjee (2020) in "States Protest Linking of Additional Borrowing Limit to Four Reforms." Times of India, May 19. Retrieved on November 22, 
2020 (https://timesofindia.indiatimes.com/business/india-business/states-protest-linking-ofadditional-borrowing-limit-to-four-reforms/articleshow/75817114.cms).

59. See Anuja, Gyan Varma. 2020."Punjab Becomes First State to Reject Centre's Farm Laws with its own Bills." Mint, October 20. Retrieved on November 22, 2020 (https://www.livemint.com/ news/india/punjab-becomes-first-state-to-negate-centre-s-farm-laws-11603195441914.html). For a discussion of the legislation and why it has faced opposition, see Inamdar, Nikhil. 2020."Farm Bills: Are India's New Reforms a 'Death Warrant' for Farmers?," BBC News, September 23. Retrieved on November 22, 2020 (https://www.bbc.com/news/world-asia-india-54233080).

60. See his opinion piece, "The Distant Goal of Cooperative Federalism," The Hindu, May 22, 2015. Retrieved on November 22, 2020 (http://www.thehindu.com/opinion/op-ed/the-distant-goalofcooperative-federalism/article7232184.ece).

\section{ABSTRACTS}

This contribution focuses on the response of India's states to the central government's controversial decision to amend the country's citizenship law. Since the legislation was passed in late 2019, a dozen states and Union territories as well as hundreds of local bodies have expressed their dissent in various ways. Mobilizing both substantive and procedural arguments, they have passed resolutions and pledged not to implement the law and related measures in their jurisdictions. The paper maps the chronology of these actions, describes the key arguments and motivations, and situates them within the broader context of India's federal system. It argues that Centre-state relations have deteriorated in recent years with increasing centralization under the leadership of the Bharatiya Janata Party, whose strong majority in Parliament has allowed it to pursue its agenda without check from coalition partners. Dissenting state governments, often taking the cue from their own mobilized citizens, are asserting their prerogative to defend and protect secular values as well as the fundamental rights contained in the Constitution. In this sense, the federal framework, operating as a power sharing mechanism, acts as a moderating force on the central government's political agenda.

\section{INDEX}

Keywords: federalism, state-level politics, Citizenship Amendment Act 2019, dissent, India

\section{AUTHOR}

\section{LORAINE KENNEDY}

CNRS Research Director, Centre d'Études de l'Inde et de l'Asie du Sud (CNRS-EHESS), Paris 